\title{
Effect of Calcium on the Phosphorus Nutrition of Rhizobium meliloti ${ }^{1}$
}

\author{
D. P. BECK AND D. N. MUNNS ${ }^{2}$
}

\begin{abstract}
Effects of calcium at 300 and $1500 \mu M$ on $P$ nutrition were assessed in eight strains of Rhizobium meliloti in defined liquid medium. Evaluations included: $P$ storage from "luxury" external concentration $(1000 \mu M P)$; utilization of stored $P$ after transfer to unreplenished low-P medium $(0.06$ $\boldsymbol{\mu M}$ ); and growth at low concentrations of $P$ buffered at $5,0.5$, and $0.06 \mu M$ with an iron oxide dialysis system. The strains stored $P$ in luxury medium, but unlike other rhizobia, they needed high $C a$ to utilize the stored $P$. They either grew or died following transfer to low-P medium, depending on the $\mathrm{Ca}$ concentration and the $\mathrm{Ca}$ concentration at which they had grown previously. Ability to grow in media buffered at low $P$ concentrations also contrasted with that of other rhizobia, in two respects: no strain of $R$. meliloti grew at $0.06 \mu M P$, regardless of $C$ a concentration; and some strains needed high Ca to grow at 0.5 and $5 \mu M$ P. Two isolates from Medicago rugosa and Melilotus indica were less Ca-demanding than six isolates from Medicago sativa. Previous reports that $R$. meliloti has low calcium requirements may be correct only for the luxury $P$ levels that are conventional in defined media. Our evidence for high $C a$ requirement at realistic $P$ concentrations agrees with data from soil experiments.
\end{abstract}

Additional Index Words. symbiotic N fixation, Fe oxide, goethite, P-buffering, uptake, utilization.

Beck, D.P. and D.N. Munns. 1985. Effect of calcium on the phosphorus nutrition of Rhizobium meliloti. Soil Sci. Soc. Am. J. 49:334337.

MINERAL NUTRITION STUDIES of plants and soil microbes in simplified artificial media become especially valuable when their results appear to contradict observations made in soils. Study of such discrepancies can uncover a previously unsuspected role for soil factors incorrectly reproduced in the artificial system. This paper reports such a case involving $\mathrm{Ca}$ and $\mathrm{P}$ nutrition of microbes important in nitrogen cycling, members of the genus Rhizobium.

There has long been evidence suggesting that in acid soils $\mathrm{Ca}$ deficiency can limit growth of Rhizobium, especially $R$. meliloti $(9,10,11)$. Yet all controlled studies of Ca nutrition of rhizobia in artificial media, even with $R$. meliloti, indicated requirements so low that $\mathrm{Ca}$ would seem unlikely ever to limit the organisms' growth in soil $(2,14)$. The artificial media, as is conventional, contained millimolar concentrations of phosphate, hundreds of times higher than the concentrations actually encountered in soil solutions. Since

\footnotetext{
' Contribution from Dep. of Land, Air and Water Resources, Univ. of California, Davis CA 95616. Supported in part by a grant from NSF RANN.Received 8 July 1983. Approved 31 Oct. 1984.

${ }^{2}$ Respectively, Research Assistant (now Microbiologist, Univ. of Hawaii NifTAL Project, Maui, HI 96779), and Professor of Soil Science, UC Davis.
}

$\mathrm{Ca}$ and $\mathrm{P}$ can interact in their transport into cells and organelles (5), we postulated a similar interaction in $R$. meliloti, such that high $\mathrm{Ca}$ becomes necessary when orthophosphate is lowered to concentrations relevant to the soil environment. This paper reports experiments testing the postulate, using a recently published procedure $(1,6)$ for controlling phosphate concentrations in the micromolar range.

\section{MATERIALS AND METHODS}

Seven strains of Rhizobium meliloti were used: five isolates from Medicago sativa (Nitragin Co. strains 102F70 and 102F28 and United States Dep. of Agric. strains 1021a, 1029, and 1031), one isolate from Medicago rugosa (Nitragin 102H1), and one isolate from Melilotus indica (Nitragin 104B4). All the strains effectively nodulated Medicago saliva var. Moapa in aseptic agar tube culture. Cultures were maintained under refrigeration on yeast-agar slants similar in composition to our liquid luxury-P medium (below).

Arabinose-galactose $(0.3 \%$ each $)$ as an energy source was chosen because it did not interfere with the phosphomolybdateblue determination of $\mathrm{P}$. The liquid media also contained 1.1 $\mathrm{g} / \mathrm{L}$ sodium glutamate, $0.1 \mathrm{mg} / \mathrm{L}$ biotin, and inorganic nutrients at the following micromolar concentrations: $\mathrm{MgSO}_{4} \quad 300$; FeEDTA 50; $\mathrm{MnSO}_{4} 2 ; \mathrm{ZnSO}_{4} 1 ; \mathrm{CUSO}_{4} \quad 0.5 ; \mathrm{Na}_{2} \mathrm{MoO}_{4} 0.1$; $\mathrm{CoCl}_{2}$ 0.02. Calcium was supplied as chloride at two concentrations: $300 \mu M$ (low-Ca) and either $1500 \mu \mathrm{M}$ or 3000 $\mu \mathrm{M}$ (high-Ca). The $\mathrm{pH}$ was adjusted to 5.5 with $\mathrm{HCl}$ before autoclaving. To maintain buffered concentrations of phosphate at low levels in solution, an "Fe oxide dialysis" system was used (6). Concentration of $\mathrm{P}$ in solution depended on the amount added with the iron oxide (powdered limonite from Ward's Natural Science Establishment, Rochester, NY). The oxide was phosphated in $150 \mathrm{~g}$ lots by shaking it for $6 \mathrm{~d}$ in $1.5 \mathrm{~L}$ of $10 \mathrm{mM}$ $\mathrm{CaCl}_{2}$ with the appropriate amount of $\mathrm{KH}_{2} \mathrm{PO}_{4}$, followed by filtration and air-drying. Each culture received a slurry of $3 \mathrm{~g}$ oxide and $4 \mathrm{~mL}$ water contained in a section of dialysis tubing knotted at both ends, added to $37 \mathrm{~mL}$ of medium in a $125 \mathrm{~mL}$ Erlenmeyer, culture flask, autoclaved $30 \mathrm{~min}$, and left $3 \mathrm{~d}$ at 25 to $27^{\circ} \mathrm{C}$ to equilibrate. The desorption isotherm was then determined by analysis of the liquid media. The luxury-P control contained $\mathrm{KH}_{2} \mathrm{PO}_{4}-\mathrm{K}_{2} \mathrm{HPO}_{4}$ at a $\mathrm{P}$ concentration of $1000 \mu M$. The low-P treatment, with no $\mathrm{P}$ added, and the oxide cultures, received $250 \mu \mathrm{M} \mathrm{K}_{2} \mathrm{SO}_{4}$ to ensure an adequate supply of $\mathrm{K}$.

All liquid cultures were incubated at $25^{\circ} \mathrm{C}$ on an orbital shaker.

Three sets of experiments were done:

1. Phosphorus storage in cells was measured at both a luxury level of $\mathrm{P}(1000 \mu \mathrm{M})$ and a high level representing that found in solution in a fertile soil $(5 \mu \mathrm{M})$. The $5 \mu \mathrm{M}$ level was maintained using the oxide dialysis system. At each level of P, two replicates each of two levels of $\mathrm{Ca}(300$ and $1500 \mu \mathrm{M}$ ) were inoculated and grown to $10^{7}$ to $10^{8}$ cells per $\mathrm{mL}$, then centrifuged at relative centrifugal force $10000 \mathrm{Xg}$ for $20 \mathrm{~min}$, resus- 
pended in $10 \mathrm{mM} \mathrm{CaCl}{ }_{2}$ and recentrifuged. The pellet was dried overnight at $60^{\circ} \mathrm{C}$, then analyzed after Kjeldahl digestion by a phosphomolybdate-blue procedure (13).

2. Growth was measured following transfer from luxury $\mathrm{P}(1000 \mu \mathrm{M})$ to unbuffered low-P $(0.06 \mu M)$ medium. High-P cells grown at two levels of $\mathrm{Ca}$ were used to inoculate low-P medium containing the two levels of calcium in a factorial experimental design. The inocula were added to $37 \mathrm{~mL}$ media to give an initial density of about $10^{\circ}$ cells per ml. Cell growth was followed by conventional drop counts on yeast arabinose-galactose plates. At each time (see Fig. 2 and 3), six replicate $41 \mu \mathrm{L}$ drops were counted from each triplicate culture. Analysis of variance was done on $\log _{o}$ transforms of the counts.

3. Growth was measured at buffered concentrations of phosphate likely to be encountered by bacteria in the soil, with the high level representing a P-fertile soil $(5 \mu M)$, medium a P-deficient soil $(0.5$ $\mu M)$, and low a P-depleted rhizosphere $(0.06 \mu M)$. The inocula were from cultures grown in high-Ca, low-P medium to eliminate $\mathrm{P}$ storage effects, and diluted to provide $10^{3}$ to $10^{4}$ cells per $\mathrm{mL}$ at the beginning of the experiment. Growth of strains 102F28, 102111, 104B4 and 1021a was monitored by drop counts at intervals for $7 \mathrm{~d}$ after inoculation into media at two levels of $\mathrm{Ca}$ and the three buffered levels of $\mathrm{P}$, plus a $2000 \mu M \mathrm{P}$ luxury control. The least significant difference (LSD, $\mathrm{p}=0.05$ ) was calculated from the analysis of variance on $\log _{10}$ transforms of the counts. The culture medium was analyzed at 3 and $5 \mathrm{~d}$ for $\mathrm{P}$ to check the P-buffering performance of the oxide, and $\mathrm{pH}$ was checked near the end of each experiment.

\section{RESULTS}

Phosphorus storage was in the same range as in other Rhizobium species (1). At $1000 \mu M \mathrm{P}$, the concentration of $\mathrm{P}$ stored varied from 1.3 to $1.9 \%$ of cell dry weight, depending on strain, but was unaffected by the level of calcium (Table 1). None of the strains grown with low $\mathrm{Ca}$ and $5 \mu \mathrm{M} \mathrm{P}$ achieved a high enough population for analysis of $\mathrm{P}$. In the $5 \mu \mathrm{M}$ P cultures, the rhizobia stored only enough $\mathrm{P}$ to support one to two generations following transfer.

Calcium level had a dramatic effect on the ability of Rhizobium meliloti strains to utilize their stored $\mathrm{P}$ upon transfer into low-P medium (Fig. 1). The amount of growth (or death) depended not only on the calcium level in the low-P media, but also on the calcium level at which the high-P inoculum had been grown. Stored $\mathrm{P}$ appeared sufficient to support three to six genera-

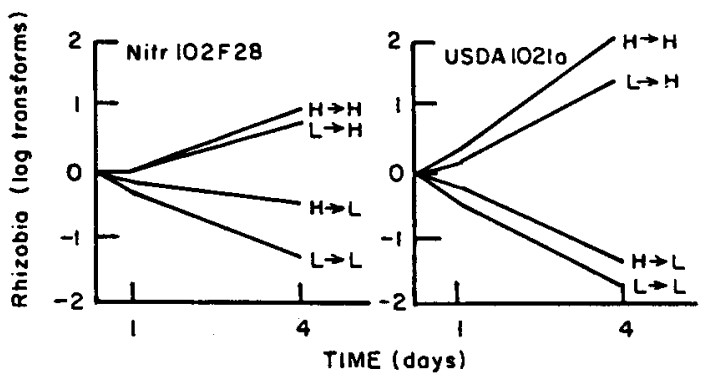

Fig. 2. Effects of $\mathrm{Ca}$ on growth of isolates from alfalfa after transfer from high-P into low-P medium. There were two $\mathrm{Ca}$ levels $(\mathrm{H}=$ $1500 \mu M$ and $L=300 \mu M$ ), applied in four combinations of preinoculation and postinoculation treatment as shown. Log transforms as in Fig. 1.
Table 1. Phosphorus accumulation by strains of $R$. meliloti.

\begin{tabular}{lccc}
\hline & \multicolumn{2}{c}{$\mathrm{mg} \mathrm{P} / \mathrm{g}$ cell dry weight } & \\
\cline { 2 - 3 } Strain & $1000 \mu M \mathrm{P}$ & $5 \mu M \mathrm{P}$ & $\begin{array}{c}\text { Generations } \\
\text { produced } \neq\end{array}$ \\
\hline $102 \mathrm{~F} 70(1) \ddagger$ & $18.6 \mathrm{a} *$ & $06.4 \mathrm{e}$ & $5.8 \mathrm{~b}$ \\
$1021 \mathrm{a} \mathrm{(2)}$ & $17.2 \mathrm{ab}$ & $05.6 \mathrm{ef}$ & $6.6 \mathrm{a}$ \\
$1031(2)$ & $15.2 \mathrm{~b}$ & $04.0 \mathrm{f}$ & $4.2 \mathrm{c}$ \\
$102 \mathrm{~F} 28(1)$ & $12.7 \mathrm{c}$ & $04.3 \mathrm{f}$ & $3.0 \mathrm{~d}$ \\
$1029(2)$ & $14.4 \mathrm{c}$ & $05.0 \mathrm{ef}$ & $4.4 \mathrm{c}$ \\
$102 \mathrm{H} 1(1)$ & $15.0 \mathrm{~b}$ & $06.2 \mathrm{e}$ & $4.2 \mathrm{c}$ \\
$104 \mathrm{~B} 4(1)$ & $15.2 \mathrm{c}$ & $04.0 \mathrm{f}$ & no growth \\
\hline
\end{tabular}

* Means followed by different letters are significantly different at the 0.05 level.

$\dagger$ In high calcium, low $\mathrm{P}, 96 \mathrm{~h}$ after transfer from $1000 \mu \mathrm{M}$ P to low $(0.06$ $\mu M) P$.

‡ Sources: (1) J. C. Burton, Nitragin Co., Milwaukee, WI. (2) H. H. Keyser, USDA, Beltsville, MD.

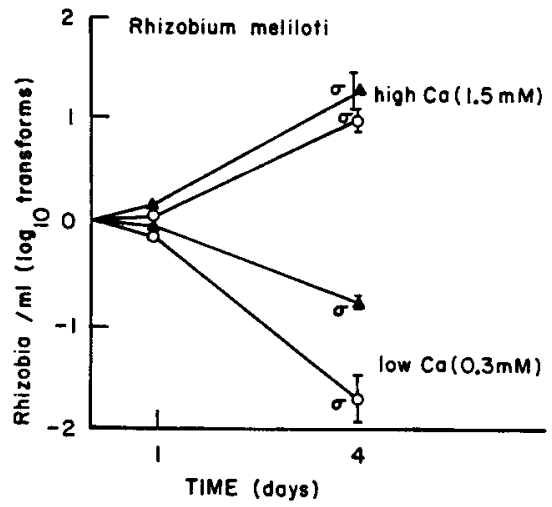

Fig. 1. Growth following transfer of cells from high-P into low-P medium at two levels of $\mathrm{Ca}$. Inocula were grown at two Ca-levels: $300 \mu M$ (circles) and $1500 \mu M$ (triangles). The transforms are $\log _{10}$ (cell count/initial cell count). Standard deviations for treatments at day 4 are indicated by vertical lines. Data are averaged over strains.

tions in high-Ca low-P medium, and growth following storage correlated fairly well with amount of P stored $R^{2}=0.85$ (Table 1). In the low-Ca low-P cultures, however, the number of viable cells decreased with time. The level of calcium at which the inocula were grown had a significant effect on subsequent growth to low P (Fig. 2 and 3). High calcium inoculum reached higher populations in high-Ca low-P medium, and remained viable longer in low-Ca low-P. Multiplication or survival varied with strain as well as calcium regime and amount of $\mathrm{P}$ stored.

Strain 102H1, isolated from Medicago rugosa, behaved similarly to the alfalfa strains in runout culture, while 104B4, isolated from Melilotus indica, would not grow at all in the low P media, regardless of cal

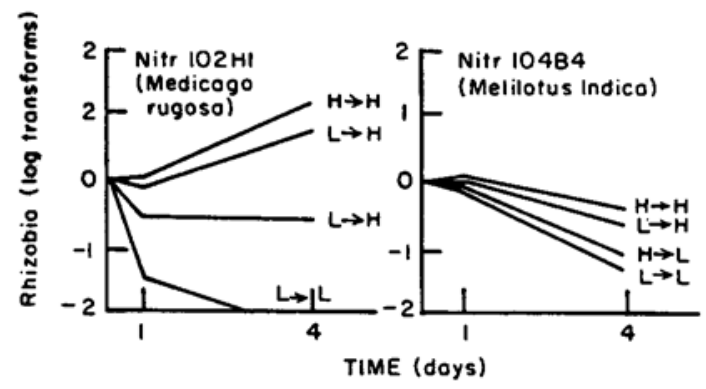

Fig. 3. "Runout" experiment on strains isolated from Medicago rugosa and Melilotus indica. Conditions and treatments as in Fig. 2. 
cium level (Fig. 3). Phosphate storage for both was in the same range as in the other $R$. meliloti strains (Table 1).

The dialysis system buffered the phosphate concentration at low levels until populations in the cultures reached $10^{6}$ to $10^{7}$ cells per $\mathrm{mL}$, at which point bacterial uptake exceeded the rate of P movement into solution (6). Accordingly, curves were plotted only as long as buffering capacity remained (through the first three days of growth).

Measurement of $\mathrm{pH}$ in culture solutions at the end of the growth period $(7 \mathrm{~d})$ indicated that all strains raised the $\mathrm{pH}$ of the media, with the magnitude of the shift corresponding to the population increase. The largest populations raised the $\mathrm{pH}$ to approximately 7.0 , while $\mathrm{pH}$ remained at 5.5 where little or no growth occurred.

No $R$. meliloti strains grew at the lowest level of $\mathrm{P}(0.06$ $\mu \mathrm{M})$, regardless of calcium level. Differences in growth became significant in isolates from alfalfa at the medium $\mathrm{P}$ level $(0.5 \mu \mathrm{M})$ after 72 h. (Fig. 4). Calcium concentration apparently affected the ability to utilize low solution $\mathrm{P}$ concentrations. Under the low calcium regime growth at $72 \mathrm{~h}$ differed between the medium and high levels of $\mathrm{P}$, but at high calcium there was essentially no difference in growth between these two P treatments (Fig. 4). Alfalfa isolates $102 \mathrm{~F} 70$ and $102 \mathrm{~F} 28$ produced an average of two generations with low $\mathrm{Ca}$ and medium $\mathrm{P}$, and an average nine generations with high $\mathrm{Ca}$ and medium $\mathrm{P}$ after $72 \mathrm{~h}$. At high $\mathrm{P}$, and also in luxury $\mathrm{P}$ media (not shown) all the strains produced about the same population regardless of calcium level after $72 \mathrm{~h}$.

The two isolates from M. rugosa and M. indica had

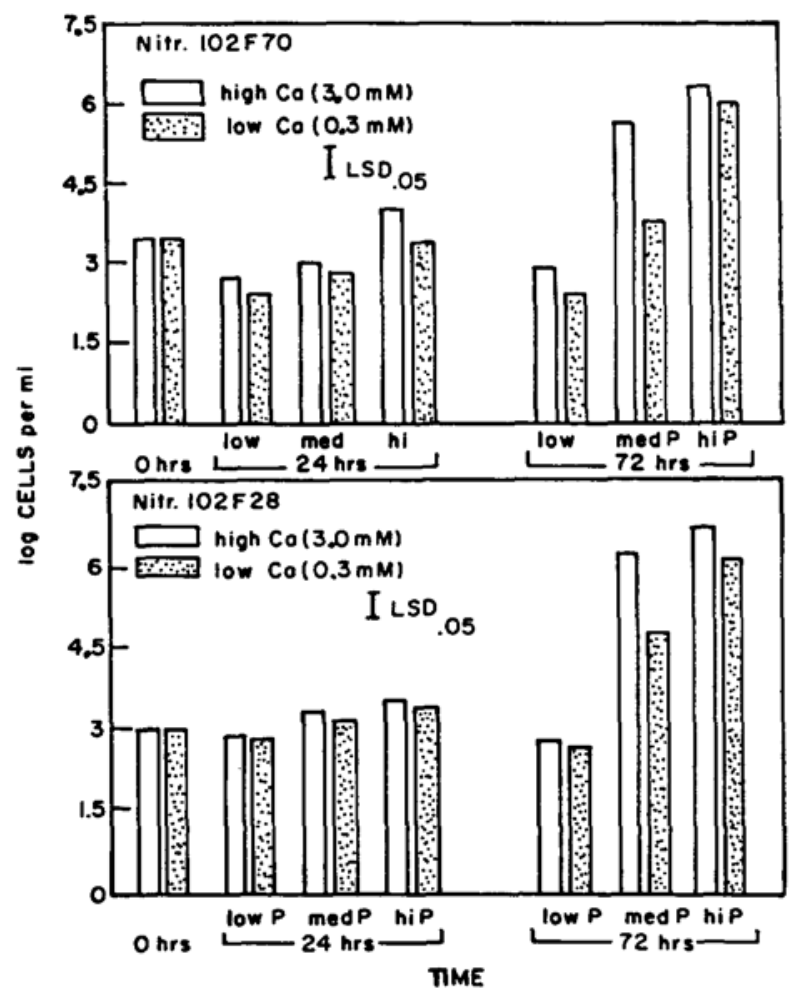

Fig. 4. Growth of two isolates from alfalfa at three buffered levels of $\mathrm{P}$ and two levels of $\mathrm{Ca}$. somewhat different requirements than those from alfalfa. These two isolates grew almost as well at low $\mathrm{Ca}$ as at high $\mathrm{Ca}$ (Fig. 5). They also grew equally at the medium and high levels of $\mathrm{P}$.

\section{DISCUSSION}

Uptake of P is generally considered an active process (3), and probably is dependent on an intact, normally formed structure of cell wall proteins. Calcium deficiency causes a loss of wall integrity, indicated by swollen, vacuolated cells and susceptibility to lysis and antibody absorption $(15,16)$. Magnesium is unable to overcome the wall deficiency. Addition of $\mathrm{Ca}$ to deficient cells does not restore normal morphology, indicating its role is played during cell wall formation. The structural role of $\mathrm{Ca}$ could be in the binding of otherwise free- $\mathrm{COOH}$ groups of the peptidoglycan layer (8), or by lending stability to the lipoprotein (14).

Bergersen (2) found that $R$. meliloti and R. trifolii had an increased lag phase and a shortened exponential phase in low $\mathrm{Ca}$ medium, while other species showed no difference with calcium treatments. All investigations into calcium requirements of Rhizobium, however, have been done at $\mathrm{P}$ levels of $1.0 \mathrm{mM}$ or higher, and are representative of conditions likely to be found only in the laboratory. The synergistic effect of $\mathrm{Ca}$ and $\mathrm{P}$ that might take place in nature, where soil solutions are generally below $3 \mu \mathrm{M}$ P (12) has not been previously considered. The data presented here show an interaction in solution culture at low levels of $\mathrm{P}$.

Improvement in nodulation due to $\mathrm{Ca}$ has been attributed to several mechanisms (10), including increased rhizobial numbers in response to an increase

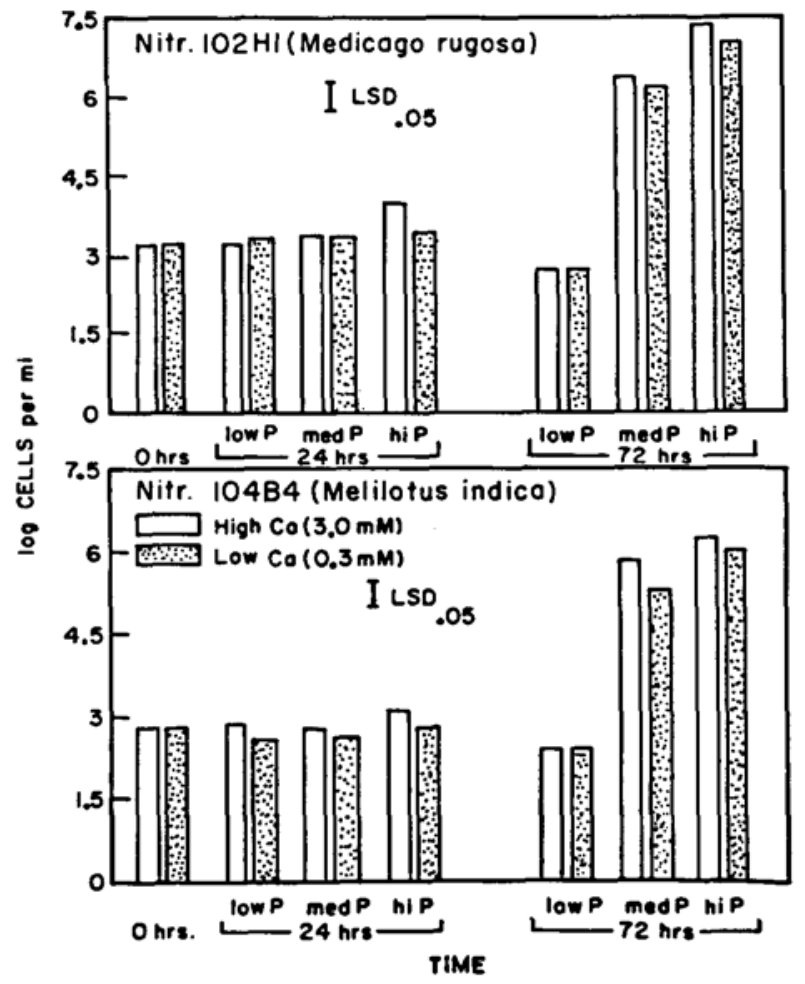

Fig. 5. Growth of isolates from Medicago rugosa and Melilotus indica at three buffered levels of $\mathbf{P}$ and two levels of $\mathrm{Ca}$. 
in calcium. In addition the direct effect of low Ca may have to do with the $\mathrm{P}$ nutrition of the rhizobia. This idea coincides with claims that P-fertilization has improved nodulation in greenhouse and field trials with several species $(7,17)$.

The greater sensitivity of Rhizobium meliloti to calcium deficiency, $(2,11)$, and subsequent $\mathrm{P}$ deficiency, suggests that the rhizobia co-evolved with hosts which are similarly sensitive (10). A loss in efficiency of extraction of $\mathrm{Ca}$ and $\mathrm{P}$ from the soil may have occurred as the symbiotic partners adapted to calcic conditions.

Phosphate requirements of the strains isolated from Medicago rugosa and Melilotus indica were less calcium dependent than those of isolates from alfalfa. Screening more alfalfa isolates might also uncover strains lacking susceptibility to calcium concentration. Further investigation is required to set limits on the $\mathrm{Ca}$ and $\mathrm{P}$ nutrition of Rhizobium meliloti as a whole, and to characterize cell morphology and behavior in a soilplant system under calcium-induced phosphate stress.

\section{REFERENCES}

Beck, D.P., and D.N. Munns. 1984. Phosphate nutrition of Rhizobium spp. J. Appl. Env. Microbiol. 47:278-282.

Bergersen, F.J. 1961. Growth of Rhizobium in synthetic media. Aust. J. Biol. Sci. 14:349-360.

Bieleski, R.L. 1973. Phosphate pools, phosphate transport, and phosphate availability. Ann. Rev. Plant Physiol. 24:225-252.
Bieleski, R.L. 1977. Passage of phosphate from soil to plant. In G.J. Blair (ed) Reviews of Rural Science: 111. The efficiency of phosphorus utilization. Univ. New England, Australia.

Bronner, F. and M. Peterlick. 1981. eds. Calcium and phosphate transport across membranes. Academic Press, N.Y.

Cassman, K.G., D.N. Munns, and D.P. Beck. 1981. Growth of Rhizobium strains at low concentrations of phosphate. Soil Sci. Soc. Am. J. 45:520-523.

DeMooy, C.J. and J. Pesek. 1966. Nodulation responses of soybeans to added P, K, and Ca salts. Agron. J. 58:275-280.

Humphrey, B.A. and J.M. Vincent. 1962. Calcium in cell walls of Rhizobium trifolii. J. Gen. Microbiol. 19:557-562.

Lowther, W.L. and J.F. Loneragan. 1970. Calcium in the nodulation of legumes. p. 446-50. Proc. 11 th Int. Grasslands Congr. Surfers' Paradise, Queensland. Apr. 1970. Univ. of Queensland Press. St. Lucia, Queensland, Australia.

Munns, D.N. 1976. Mineral nutrition and the legume symbiosis. p. 353392. In R.W.F. Hardy and A.H. Gibson (ed.) Treatise on dinitrogen fixation, Vol. 4. John Wiley and Sons, New York. Norris, D.O. 1959. The role of $\mathrm{Ca}$ and $\mathrm{Mg}$ in the nutrition of Rhizobium. Aust. J. Agri. Res. 19:675-683.

Reisenauer, H.M. 1966. Mineral nutrients in soil solution. p. 507509. In P.L. Altman and D.S. Dittman. (ed.) Environmental Bi-ology. Fed. Am._Soc. for Exp. Biol. Bethesda, MD.

Throneberry, G.O. 1974. Phosphorus and Zn measurements in Kjeldahl digests. Anal. Biochem. 60:358-362.

Vincent, J.M. 1977. Rhizobium: General Microbiology. pp. 277367. In W.S. Silver (ed.) A treatise on dinitrogen fixation, Vol. 3. Wiley and Sons, New York.

Vincent, J.M. and B.A. Humphrey. 1963. Partition of divalent cations between bacterial wall and cell contents. Nature 199:149153.

Vincent, J.M. and B.A. Humphrey. 1968. Modification of the antigenic surface of Rhizobium trifolii by a deficiency of calcium. J. Gen. Microbiol. 54:397-405.

Wendt, W.B. 1971. Effects of inoculation and fertilizers on Desmodium intortum at Serere, Uganda. E. Aft. Agr. For. J. 36:317321. 